\title{
INVESTMENTS IN R\&D AS A DETERMINANT OF INNOVATION IN THE ECONOMY
}

\begin{abstract}
Goal - The main aim of this article is to examine investments in R\&D in relation to the gross domestic product as the main factor for the development of innovation in each country. Moreover, the article shows the distribution of $R \& D$ expenditure between four main sectors in order to find out which sector plays the most important role in terms of the long-term stability of R\&D activity.

Research methodology - The author uses the results of gross expenditures on R\&D prepared by Eurostat.

Score - The results of gross domestic expenditure on R\&D lead to conclusion that the more funds spent on R\&D activity, the greater the level of innovation was achieved in EIS ranking. What is more, there is a regularity in the geographical distribution of the most innovative countries in the north. In the central part there are strong innovative countries. Whereas in the south and in the east, there are moderately innovative countries. Additionally, in most EU countries the structure of expenditure on R\&D by institutions/organizations financing this activity is in the following order due to the largest share: business sector, higher education sector, government sector and non-profit sector.

Originality/value - The use of Eurostat data to approach unconventional R\&D sector and the subject of innovation.
\end{abstract}

Keywords: Schumpeter's theory, research and development, innovation, European Union Scoreboard, gross domestic expenditure

DOI: 10.15290/wpewbmn4.2020.07

\section{Introduction}

The subject of the article are investments in the activity of research and development as the main factor for the development of innovation. The most important motive for undertaking the research was the willingness to analyze expenditure in the $R \& D$ sector in relation to the gross domestic product in order to compare the results with position in ranking European Innovation Scoreboard. The purpose of 
the article is to try to answer the research question, whether expenditure on $R \& D$ activity contributes to increase the level of innovative economy.

As long as we know what are key indicators for development economy, we are able to grasp and control them. Many say R\&D is increasingly important subject in the new economy. It is often argued that the invention is an innovation. Apart from of course medical innovations, which are significantly vital for human beings, every invention needs market success. It is crucially important what invention can bring to our daily life. Even though we launch the product on the market and this product has been defined by the consumers as useless, would it still be considered as the innovation? What is the profit of invention did in a garage if it did not achieve market success? It is more than sure that the invention did in a garage will disappear in the dark side of the market without market success. Innovation is a process, which covers: invention plus market success.

The article contains five parts. The purpose of the first part is to present the iss. of innovation in economic theory. In the second part, the author approaches the subject of research and development, with particular emphasis on the observation of the entrepreneurs' market. The third part analyzes the gross domestic spending on the activity of $R \& D$ and the European Innovation Scoreboard. It also presents the structure of expenditure on R\&D by institutions/organizations financing this activity. The fourth part contains the analysis of $R \& D$ activity in Poland in terms of intramural expenditure. The last part includes summary and conclusion.

\section{Innovation in economic theory}

The most popular definition of research and development activity includes "creative work undertaken in a systematic manner to increase knowledge resources and use them to create new applications" ${ }^{\prime}$. Therefore, R\&D activity means that any creative work, which leads to create new applications.

The first innovation model was based on Schumpeter's theory. It was a linear innovation model consisting of clearly defined sequence stages, consecutive chronological order. That innovation model dominated in the period from 1950 to the end of 1980. Schumpeter as a first scientist defined the process of innovation development in the following way: “(...) innovations in the economy do not usually take place in such a way, that spontaneously new needs arise in consumers, and then, under their pressure, the production apparatus is shifted". Indeed, such a process occurs in the economy, however the producer is the initiator. According to Schumpeter's theory, "if the new combinations occur in a non-continuous way, then a phenomenon characteristic of development arises". Schumpeter thinks that development is based on new combinations of production factors ${ }^{2}$.

${ }_{1}$ Podręcznik Frascati, Pomiar działalności naukowo-technicznej i innowacyjnej, Główny Urząd Statystyczny, OECD Publishing, Warszawa 2018.

2 J.A. Schumpeter, Teoria rozwoju gospodarczego, Wydawnictwo Naukowe PWN, Warszawa 1960, p. 103. 
Joseph Aloïs Schumpeter gives 5 cases of development to illustrate what innovation is. These are: launching a new product or a new product species on the market (product innovation), introduction of a new production method that does not have to be based on a scientific invention, but for example on a new commercial procedure with products (process innovation), opening a new market, for instance a new market for which the industry branch of the country has not been previously introduced (market innovation), capture a new source of raw materials or semi-finished products, introducing a new organization of an industry, for example creating a monopoly situation or breaking the monopolistic situation ${ }^{3}$.

Innovations were also studied by scientists such as A.J. Harman, D.E. Hagen, J. Parker and P.R. Whitfield, who understood the term of innovation as a scheme of complex actions consisting in solving problems. The result is a comprehensive and developed quality 4 . One-way approach to term of innovation was represented by Christopher Freeman. He identified innovation with the first commercial introduction of a product, process, system or device ${ }^{5}$.

Peter Ferdinand Drucker had a different perception of innovation for the above scientists, who claimed that innovation is a conscious and beneficial change resulting from the needs or systematic observation of the environment ${ }^{6}$. Summing up the observations and definitions innovation is identified with something new in every aspect of human activity, as long as knowledge is the main stimulus.

Schumpeter in his theory defines innovation in relation to the production function, which describes how the size of production changes when the quantity of production changes. However, if the quantity of production does not change, and the form of the production function changes, then we achieve innovation ${ }^{7}$. The basic approach to research and development activity is broken down by functional criterion. The process of creating innovative solutions in macroeconomics terms comprises 5 stages $^{8}$ :

1. Basic research - Investigation and analysis focused on a better or fuller understanding of a subject, phenomenon, or a basic law of nature instead of on a specific practical application of the results.

2. Applied research - Investigation of the findings of 'pure' or basic research to determine if they could be used to develop new products or technologies. Also, the research conducted to solve specific problems or to answer specific questions. In accounting for research and development costs, the

\footnotetext{
3 J.A. Schumpeter, Teoria rozwoju gospodarczego, Wydawnictwo Naukowe PWN, Warszawa 1960, p. 104.

4 P.R. Whitfield, Innowacje $w$ przemyśle, transl. T. Mroczkowski, PWE, Warszawa 1979, p. 26.

5 W. Janasz, K. Kozioł, Determinanty działalności innowacyjnej przedsiębiorstw, PWE, Warszawa 2007, p. 14.

6 P.F. Drucker, Innowacje i przedsiębiorczość. Praktyka i zasady, PWE, Warszawa 1992, s. 40-45.

7 J.A. Schumpeter, Business Cycles. A Theoretical, Historical and Statistical Analysis of the Capitalist Process, McGraw Hill, New York 1964, p. 64.

8 A. Pomykalski, Zarządzanie innowacjami, Wydawnictwo Naukowe PWN, Warszawa - Łódź 2001, p. 35-45.
} 
development costs may be carried forward but the basic and applied research costs are often written off as incurred.

3. Development works that can lead to the creation of a prototype.

4. Innovations understood as the first commercial application of new solutions.

5. Diffusion of innovation involving the use of innovative solutions in subsequent entities or new applications.

According to the presented model, the innovation process is an integrated process of activities. The most important area of the process, apart from scientific research, is the role of enterprises. Creating innovative solutions requires human capital owned by the company. In many cases, it is knowledge that is sufficient to implement innovation. However, it is often necessary to raise the professional qualifications and skills of employees to introduce innovations in the enterprise.

If it is assumed that the phases sequence in the above statement corresponds to reality, then the so-called linear model of the innovation model is created. There are two general hypotheses how to make impulse to start the process. The first one is scientific researches, which deliver new solutions and start other phases in the process. The second one is that the impulse of innovations is potential market, which identified new needs by enterprises. Today's economy is combination of both.

In economic theory there are four types of innovations due to objective scope ${ }^{9}$ :

1. product innovation,

2. process innovation,

3. marketing innovation,

4. organizational innovation.

The first type includes changes occurring within products and services. The second one concerns changes in production methods. The third one includes changes in product design, packaging, promotion, distribution or pricing of products and services. The fourth one involves implementation of organizational methods.

\section{Outline of research and development activity against the background of market observations}

Basically, R\&D is based on intangible assets such as: knowledge (Human Capital) and technology (scientific equipment). According to OECD definition, R\&D covers three activities: basic research, applied research, and experimental development. Basic research is experimental or theoretical work undertaken to acquire new knowledge without any particular application or use in view. Applied research is also original investigation undertaken in order to acquire new knowledge, directed primarily towards a specific practical aim or objective. Experimental development

${ }_{9}$ K. Fonfara, Marketing partnerski na rynku przedsiębiorstw, PWE, Warszawa 2014, p. 65. 
is a systematic work, drawing on existing knowledge gained from research and practical experience, which is directed to producing new materials, products or devices, to installing new processes, systems and services, or to improving those already installed ${ }^{10}$.

The main measure for comparing countries in terms of innovation development is gross domestic expenditure on R\&D. They contain total expenditure, current and capital, for research and development carried out throughout the entire $R \& D$ sector. The $R \& D$ sector includes all business entities (including enterprises, including natural persons conducting economic activity and institutions) involved in defined creative work. Research and development centers are usually created as a result of foreign investments as well as investments of local universities and companies. State authorities and local government involve public funds for research and development activity. The goal main is to generate technologies and employment-friendly infrastructure. These activities are conducive to the emergence of innovations in the R\&D sector.

For companies locating their $R \& D$ centers in Poland, bearing a greater financial burden than their competitors in other countries, discourages further development, or constitutes argument for choosing a seat in a country with a more favorable tax system ${ }^{11}$. Main market observations on investments in R\&D sector in Poland in 2014 were prepared by International Company PWC and National Centre for research and development in Poland. These are five observations selected by the author ${ }^{12}$ :

1. $80 \%$ of entrepreneurs assume an increase in expenditure on $R \& D$.

2. The first profits from R\&D activity appear on average after 2 and half years from the implementation of results. Enterprises indicate that the maximum time they are able to accept the return on investment in R\&D is 3 years. At the same time, as to the expected minimum rate, most companies pointed out the return on investment in $R \& D$ on the level of $10 \%$.

3. $41 \%$ of new products introduced to the market in 2014 it was the result of $\mathrm{R} \& \mathrm{D}$ activity.

4. Entrepreneurs are quite active in implementing $R \& D$ projects in partnership. In the last 3 years, $43 \%$ of projects implemented by large enterprise was implemented in partnership, while in small and medium-sized enterprises $16 \%$ of projects.

5. Entrepreneurs mainly cooperate with universities and other entrepreneurs, and it is with these partners that they value cooperation the most (33\% of indications concern universities, and $24 \%$ of other entrepreneurs).

\footnotetext{
${ }^{10}$ Science and Technology, Research and Development, http://www.oecd.org/sdd/08_Science_ and_technology.pdf [accessed: 23.06.2019].

${ }^{11}$ A. Miarkowski, Ulżyć innowacjom: Uwagi do projektu zmian w uldze podatkowej na działalność badawczo-rozwojowa, Centrum Analiz Klubu Jagiellońskiego, Kraków 2016.

${ }^{12}$ Opłacalność inwestowania $w$ badania $i$ rozwój, https://www.pwc.pl/pl/publikacje/assets/ ncbr-pwc-oplacalnosc-inwestycji.pdf [accessed: 23.06.2019].
} 
The largest motivators for the development of R\&D's business activities are the opportunity to acquire subsidies, tax deductions due to conducting R\&D work and greater flexibility and dynamics of scientific units and research. In the case of expected changes in the law, mainly tax and accounting law was indicated, which is also related to tax deductions on R\&D. Entrepreneurs deciding on the implementation of the $R \& D$ project consider primarily probability of success and project costs.

\section{The structure of gross domestic expenditure on R\&D in EU members in comparison with the European Innovation Scoreboard}

In individual countries, the implementation of expenditure on $R \& D$ is carried out in different subject arrangements. One of the dilemmas remains the iss. of the type of entities that will take responsibility for the implementation of expenditure on R\&D. The state can mobilize to carry out research and development activities through properly implemented innovation policy, including the division of public funds. Estimation of expenditures on innovative activity is undoubtedly a method of assessing innovative processes. Disbursement control is used to show the relation of expenses to the achieved innovative goals. Gross expenditure on the R\&D activity is not an ideal and the only measure of the growth of innovation development in a given country, but it is the starting point. It gives researchers the basis for the further exploring determinants of innovative economy. Comparing countries in terms of expenditure on $R \& D$ allows to see assessment of expenditure dynamics and assessment in the context of the European Innovation Scoreboard. The table below presents gross expenditure on the activity of R\&D in the European Union in the years 2013-2017 and what the expenditure target was assumed.

Dark grey colour means innovations leaders. Medium grey are strong countries in terms of innovation. Light grey colour are moderate innovators. In contrast, white colour means modest innovator. This classification was adopted on the basis of the European Innovative Scoreboard in order to show the full picture of expenditure on the business of $R \& D$ and the actual level of innovation among the countries of the European Union.

Table 1.

Gross domestic expenditure on R\&D in the EU

\begin{tabular}{l|c|c|c|c|c|c}
\hline Country/Year & 2013 & 2014 & 2015 & 2016 & 2017 & Target \\
\hline Austria & 2.95 & 3.08 & 3.05 & 3.13 & 3.16 & 3.76 \\
\hline Belgium & 2.33 & 2.39 & 2.46 & 2.55 & 2.58 & 3 \\
\hline Bulgaria & 0.64 & 0.79 & 0.96 & 0.78 & 0.75 & 1.5 \\
\hline Croatia & 0.81 & 0.78 & 0.84 & 0.86 & 0.86 & 1.4 \\
\hline Cyprus & 0.48 & 0.51 & 0.48 & 0.53 & 0.56 & 0.5 \\
\hline
\end{tabular}




\begin{tabular}{l|c|c|c|c|c|c}
\hline Country/Year & 2013 & 2014 & 2015 & 2016 & 2017 & Target \\
\hline Czechia & 1.9 & 1.97 & 1.93 & 1.68 & 1.79 & 1 \\
\hline Denmark & 2.97 & 2.91 & 3.06 & 3.1 & 3.05 & 3 \\
\hline Estonia & 1.72 & 1.43 & 1.47 & 1.25 & 1.29 & 3 \\
\hline Finland & 3.29 & 3.17 & 2.89 & 2.74 & 2.76 & 4 \\
\hline France & 2.24 & 2.23 & 2.27 & 2.25 & 2.19 & 3 \\
\hline Germany & 2.82 & 2.87 & 2.91 & 2.92 & 3.02 & 3 \\
\hline Greece & 0.81 & 0.83 & 0.96 & 0.99 & 1.13 & 1.2 \\
\hline Hungary & 1.39 & 1.35 & 1.36 & 1.2 & 1.35 & 1.8 \\
\hline Ireland & 1.56 & 1.5 & 1.19 & 1.19 & 1.05 & 2 \\
\hline Italy & 1.31 & 1.34 & 1.34 & 1.37 & 1.35 & 1.53 \\
\hline Latvia & 0.61 & 0.69 & 0.63 & 0.44 & 0.51 & 1.5 \\
\hline Lithuania & 0.95 & 1.03 & 1.04 & 0.84 & 0.89 & 1.9 \\
\hline Luxembourg & 1.3 & 1.26 & 1.28 & 1.3 & 1.26 & 2.3 \\
\hline Malta & 0.77 & 0.71 & 0.74 & 0.57 & 0.54 & 2 \\
\hline Netherlands & 1.93 & 1.98 & 1.98 & 2 & 1.99 & 2.5 \\
\hline Poland & 0.87 & 0.94 & 1 & 0.96 & 1.03 & 1.7 \\
\hline Portugal & 1.33 & 1.29 & 1.24 & 1.28 & 1.33 & 2.7 \\
\hline Romania & 0.39 & 0.38 & 0.49 & 0.48 & 0.5 & 2 \\
\hline Slovakia & 0.82 & 0.88 & 1.17 & 0.79 & 0.88 & 1.2 \\
\hline Slovenia & 2.58 & 2.37 & 2.2 & 2.01 & 1.86 & 3 \\
\hline Spain & 1.27 & 1.24 & 1.22 & 1.19 & 1.2 & 2 \\
\hline Sweden & 3.3 & 3.14 & 3.26 & 3.27 & 3.4 & 4 \\
\hline Knited & 1.64 & 1.66 & 1.67 & 1.68 & 1.66 & $:$ \\
\hline Kingdom & & & & & & 2 \\
\hline
\end{tabular}

: - data not available

Source: Gross domestic expenditure on R\&D by sector \% of GDP, https:/ /ec.europa.eu/eurostat/ web/products-datasets/product?code=sdg_09_10 [accessed: 23.06.2019].

The table 1 on the subject of expenditures of the countries of the European Union on R\&D in relation to GDP is diversified. In 2013 Sweden and Finland spent more than $3 \%$ of GDP on R\&D activity, while countries that spent less than $1 \%$ are Bulgaria, Croatia, Cyprus, Greece, Latvia, Lithuania, Malta, Poland, Romania and Slovakia. All countries were not highly innovative economics and the aim of European Union was to change this. In 2015 Bulgaria incurred the largest increase in gross domestic expenditure on R\&D in relation to 2013 and it was nearly $1 \%$.

The biggest amount of gross expenditures on R\&D activity in 2017(over 2.5\% of GDP) has been spent by countries such as: Austria, Belgium, Denmark, Finland, Germany and Sweden. In 2017 there are two countries, which spent less than 1\% of GDP on R\&D activity and has become modest innovator. There are Bulgaria and 
Romania. While Bulgaria has made progress in 2013-2015 to then made regress in the end of 2017, Romania has made successive growth in 5 years.

Countries that have made growth in expenditures on R\&D in five years are: Austria, Belgium, Bulgaria, Croatia, Cyprus, Denmark, Germany, Greece, Italy, Netherlands, Poland, Romania, Slovakia, Sweden and United Kingdom. The biggest growth in the expenditures on R\&D has been made by Austria. The rest countries of European Union have reduced the amount of financial resources on $R \& D$ activity. The largest reduction in the expenditures on R\&D has been made by Finland, Slovenia and Estonia.

It is worth emphasizing which country reach a target of gross domestic expenditure on R\&D activity in the EU. Czechia is an exception because it has set a lower target than the expenditures actually were. However, Denmark and Germany are the only country which reach a set target.

Poland spent $1.03 \%$ of GDP for investment in R\&D in 2017. It has increased over 5 years from $0.87 \%$ to $1.03 \%$. The assumed target of expenditure on R\&D activity for Poland in 2017 was $1.7 \%$ of GDP. Unfortunately, the target was not achieved. Economic policy may have an impact on the overall level of R\&D expenditure. In the case of Poland, two challenges are particularly important. First of all, it is to ensure fiscal capacity to implement tax incentives. Secondly, directly increase development expenditures. For companies that locate their R\&D centers in Poland, bear greater financial burdens than their competitors in other countries, discourages further development, or constitutes an argument for choosing a registered office in a country with more favorable tax system ${ }^{13}$.

Another aspect to consider in the article is that the conducted research includes The European Innovation Scoreboard, which is a tool for measuring and comparing the level of innovation in the European Union members. EIS is designed by the European Commission and the University of Maastricht to implement the Lisbon Strategy. In addition to EU countries, it also includes: Croatia, Turkey, Iceland, Norway, Switzerland and references to the United States and Japan. The main goal of this tool is to increase the level of innovation in European Union. EIS analyses the relative strengths and weaknesses of individual countries research and innovation systems. EIS includes 26 indicators grouped in five categories. These indicators relate to criteria, such as: human resources, attractiveness of the research system, innovation-friendly environment, $R \& D$ expenditure in the business sector, by SMEs or private co-funding of public R\&D, number of patents and trademarks. Measures are innovative achievements of the given countries, collected on the basis of various sources, first of all the International Innovation Survey Program, Eurostat and OECD. The results are presented in the EIS report issued each year by the European Commission ${ }^{14}$.

\footnotetext{
${ }_{13}$ A. Miarkowski, Ulżyć innowacjom....

${ }^{14}$ UK improves innovation performance but drops off EU's leaders group, https://ec.europa.eu/ unitedkingdom/news/uk-improves-innovation-performance-drops-eus-leaders-group_en [accessed: 23.06.2019].
} 
Table 2 .

European Innovation Scoreboard 2013-2017

\begin{tabular}{|c|c|c|c|c|c|}
\hline Country/Year & 2013 & 2014 & 2015 & 2016 & 2017 \\
\hline Austria & 119 & 115 & 117 & 122 & 121 \\
\hline Belgium & 118 & 118 & 118 & 123 & 124 \\
\hline Bulgaria & 42 & 44 & 46 & 47 & 48 \\
\hline Croatia & 54 & 49 & 54 & 54 & 54 \\
\hline Cyprus & 91 & 79 & 83 & 79 & 81 \\
\hline Czechia & 84 & 84 & 85 & 84 & 87 \\
\hline Denmark & 146 & 143 & 144 & 141 & 140 \\
\hline Estonia & 92 & 88 & 91 & 82 & 83 \\
\hline Finland & 133 & 130 & 133 & 134 & 136 \\
\hline France & 107 & 109 & 112 & 116 & 116 \\
\hline Germany & 129 & 125 & 125 & 124 & 127 \\
\hline Greece & 71 & 62 & 65 & 68 & 69 \\
\hline Hungary & 65 & 66 & 67 & 68 & 70 \\
\hline Ireland & 109 & 110 & 111 & 121 & 123 \\
\hline Italy & 75 & 77 & 79 & 77 & 78 \\
\hline Latvia & 45 & 55 & 62 & 58 & 60 \\
\hline Lithuania & 60 & 58 & 64 & 77 & 75 \\
\hline Luxemburg & 132 & 126 & 131 & 131 & 128 \\
\hline Malta & 73 & 82 & 85 & 79 & 85 \\
\hline Netherlands & 128 & 126 & 129 & 131 & 136 \\
\hline Poland & 52 & 50 & 52 & 55 & 57 \\
\hline Portugal & 84 & 81 & 83 & 83 & 85 \\
\hline Romania & 40 & 32 & 30 & 32 & 33 \\
\hline Slovakia & 71 & 66 & 69 & 70 & 68 \\
\hline Slovenia & 96 & 98 & 97 & 98 & 98 \\
\hline Spain & 77 & 71 & 73 & 78 & 84 \\
\hline Sweden & 147 & 144 & 145 & 148 & 149 \\
\hline United Kingodm & 110 & 116 & 119 & 128 & 128 \\
\hline
\end{tabular}

Source: European Innovation Scoreboard 2018, https://www.interregeurope.eu/policylearning/ news/3806/european-innovation-scoreboard-2018/ [accessed: 23.06.2019].

The table 2 presents the results that what each country achieved in EIS ranking. Innovation leaders in European Union is Sweden, which achieved 149 points in EIS ranking. Then, there are also others innovative leaders in EU such as: Denmark, Finland, Luxemburg, Netherlands and United Kingdom. The second group are strong innovators: Austria, Belgium, France, Germany, Ireland and Slovenia. The third group are moderate innovators countries such as: Czech Republic, 
Latvia, Poland, Portugal, Hungary, Spain. There are only two modest innovative countries in EU: Bulgaria and Romania and they spent the least financial resources on $R \& D$ activity. It should also be considered that expenditure on $R \& D$ is only one element of the EIS. Nevertheless, most of the innovative phenomena occur in the area of $R \& D$. Therefore, expenditure itself is a stimulus in the innovation chain of economies.

Picture 1.

European Innovation Scoreboard 2018

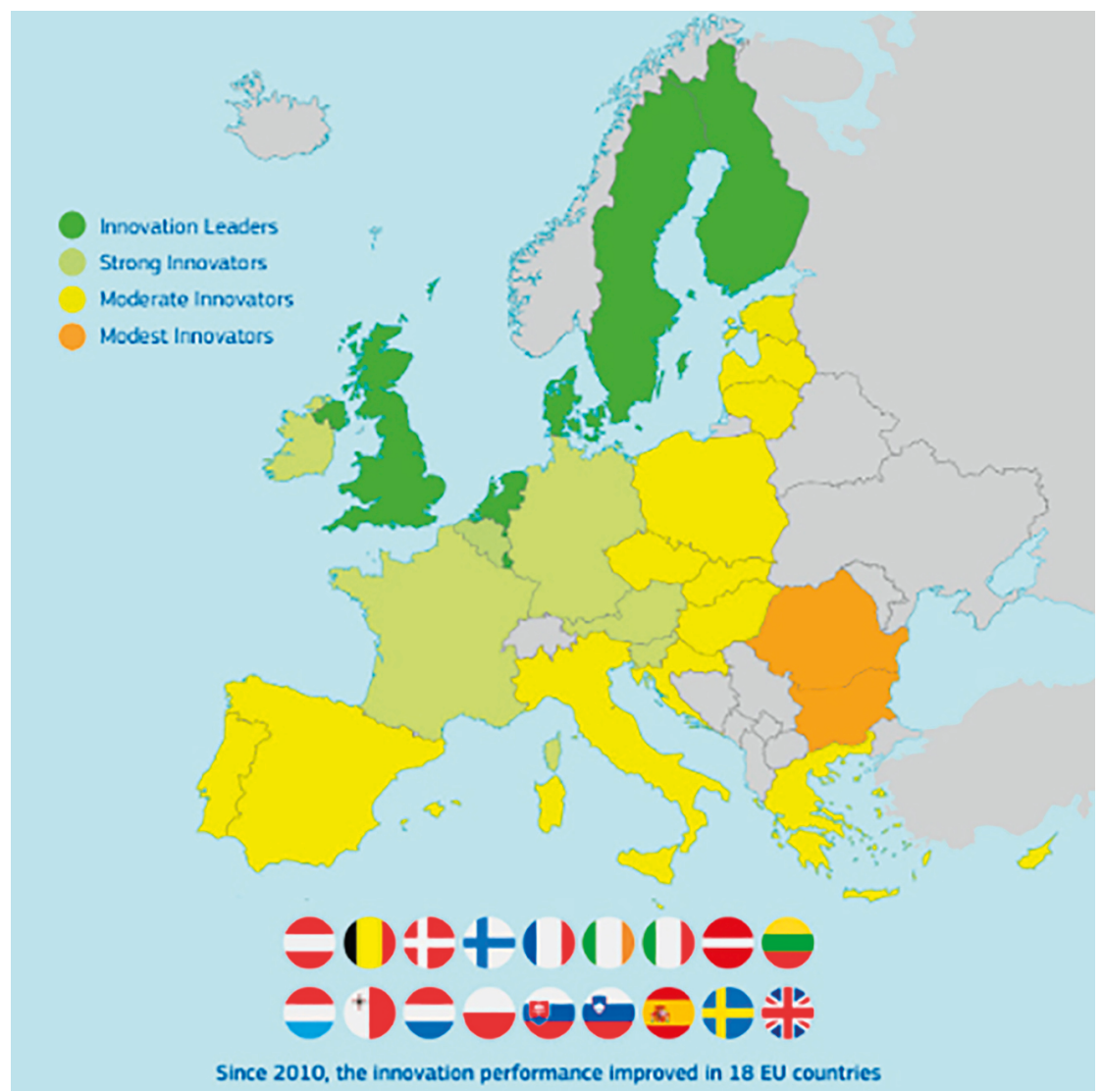

Source: European Innovation Scoreboard 2018, https://www.interregeurope.eu/policylearning/ news/3806/european-innovation-scoreboard-2018/ [accessed: 23.06.2019].

The picture 1 shows European Union countries due to the level of innovation according to the EIS ranking. There is a certain regularity in the geographic distribution of countries in terms of the level of innovation. First of all, the most innovative leaders are in the north. Then, in the central Europe there are strong innovative countries. In the east, in the west and in the south of Europe there are moderate innovator. In the far East by the Black Sea are the two weakest countries in terms of innovation: Bulgaria and Romania. 
Apart from the level of expenditure on $R \& D$ in relation to GDP, an important factor is the structure of expenditure on R\&D by institutions/organizations financing this activity. Therefore, expenditure on $R \& D$ includes expenditure from five sectors: business sector, higher education sector, government sector, non-profit sector and foreign sector. However, Eurostat statistics on which this article is based consider only four sectors, i.e. excluding the foreign sector. The following analysis presents data from Eurostat relating to these four sectors.

Table 3.

Gross domestic expenditure on R\&D by business enterprise sector

\begin{tabular}{|c|c|c|c|c|c|}
\hline Country/Year & 2013 & 2014 & 2015 & 2016 & 2017 \\
\hline Austria & 2.09 & 2.2 & 2.18 & 2.19 & 2.22 \\
\hline Belgium & 1.62 & 1.67 & 1.72 & 1.78 & 1.76 \\
\hline Bulgaria & 0.39 & 0.52 & 0.7 & 0.57 & 0.53 \\
\hline Croatia & 0.41 & 0.38 & 0.43 & 0.4 & 0.42 \\
\hline Cyprus & 0.09 & 0.11 & 0.11 & 0.2 & 0.2 \\
\hline Czechia & 1.03 & 1.1 & 1.05 & 1.03 & 1.13 \\
\hline Denmark & 1.88 & 1.86 & 1.94 & 2.02 & 1.97 \\
\hline Estonia & 0.82 & 0.62 & 0.68 & 0.64 & 0.61 \\
\hline Finland & 2.26 & 2.15 & 1.93 & 1.81 & 1.8 \\
\hline France & 1.44 & 1.45 & 1.44 & 1.43 & 1.42 \\
\hline Germany & 1.9 & 1.94 & 2 & 1.99 & 2.09 \\
\hline Greece & 0.27 & 0.28 & 0.32 & 0.42 & 0.55 \\
\hline Hungary & 0.96 & 0.97 & 1 & 0.89 & 0.99 \\
\hline Ireland & 1.12 & 1.08 & 0.85 & 0.84 & 0.74 \\
\hline Italy & 0.72 & 0.76 & 0.78 & 0.83 & 0.83 \\
\hline Latvia & 0.17 & 0.24 & 0.15 & 0.11 & 0.14 \\
\hline Lithuania & 0.24 & 0.32 & 0.29 & 0.29 & 0.32 \\
\hline Luxembourg & 0.68 & 0.68 & 0.66 & 0.7 & 0.68 \\
\hline Malta & 0.4 & 0.39 & 0.38 & 0.35 & 0.34 \\
\hline Netherlands & 1.07 & 1.11 & 1.11 & 1.16 & 1.17 \\
\hline Poland & 0.38 & 0.44 & 0.47 & 0.63 & 0.67 \\
\hline Portugal & 0.63 & 0.6 & 0.58 & 0.62 & 0.67 \\
\hline Romania & 0.12 & 0.16 & 0.21 & 0.27 & 0.29 \\
\hline Slovenia & 1.97 & 1.83 & 1.67 & 1.52 & 1.39 \\
\hline Slovakia & 0.38 & 0.32 & 0.33 & 0.4 & 0.48 \\
\hline Spain & 0.67 & 0.65 & 0.64 & 0.64 & 0.66 \\
\hline Sweden & 2.28 & 2.11 & 2.27 & 2.27 & 2.42 \\
\hline United Kingdom & 1.05 & 1.08 & 1.1 & 1.13 & 1.12 \\
\hline
\end{tabular}

Source: Gross domestic expenditure on R\&D by sector \% of GDP, https://ec.europa.eu/eurostat/ databrowser/view/sdg_09_10/default/table?lang=en [accessed: 21.09.2019]. 
Data for 2013-2017 shows that the business sector prevails in the structure of expenditure on $R \& D$. Comparing the business sector expenditure with the overall expenditure, it should be stated that the enterprise sector covers $R \& D$ expenditure at the level of $2 / 3$. At the national level, the goal set by the Lisbon Strategy of having $2 / 3$ of the expenditure on R\&D financed by the business sector has been achieved, among others, by: Austria, Belgium, Bulgaria, Germany, Hungary, Ireland, Slovenia, Sweden and United Kingdom. Only few countries haven't made growth in expenditure on R\&D activity in five years and there are: Estonia, Finland, France, Ireland, Latvia, Malta Slovenia and Spain.

Table 4.

Gross domestic expenditure on R\&D by higher education sector

\begin{tabular}{|c|c|c|c|c|c|}
\hline Country/Year & 2013 & 2014 & 2015 & 2016 & 2017 \\
\hline Austria & 0.72 & 0.73 & 0.72 & 0.69 & 0.7 \\
\hline Belgium & 0.51 & 0.49 & 0.5 & 0.52 & 0.54 \\
\hline Bulgaria & 0.06 & 0.07 & 0.05 & 0.04 & 0.04 \\
\hline Croatia & 0.2 & 0.2 & 0.2 & 0.28 & 0.25 \\
\hline Cyprus & 0.26 & 0.25 & 0.24 & 0.21 & 0.23 \\
\hline Czechia & 0.52 & 0.5 & 0.48 & 0.34 & 0.35 \\
\hline Denmark & 1.01 & 0.98 & 1.04 & 1 & 0.98 \\
\hline Estonia & 0.73 & 0.63 & 0.61 & 0.44 & 0.51 \\
\hline Finland & 0.71 & 0.72 & 0.71 & 0.69 & 0.7 \\
\hline France & 0.47 & 0.46 & 0.5 & 0.49 & 0.45 \\
\hline Germany & 0.51 & 0.51 & 0.5 & 0.53 & 0.52 \\
\hline Greece & 0.3 & 0.31 & 0.36 & 0.32 & 0.32 \\
\hline Hungary & 0.2 & 0.18 & 0.17 & 0.13 & 0.18 \\
\hline Ireland & 0.37 & 0.35 & 0.29 & 0.3 & 0.26 \\
\hline Italy & 0.37 & 0.36 & 0.34 & 0.33 & 0.33 \\
\hline Latvia & 0.26 & 0.28 & 0.31 & 0.19 & 0.24 \\
\hline Lithuania & 0.52 & 0.54 & 0.58 & 0.33 & 0.32 \\
\hline Luxembourg & 0.24 & 0.21 & 0.24 & 0.25 & 0.25 \\
\hline Malta & 0.3 & 0.25 & 0.24 & 0.21 & 0.2 \\
\hline Netherlands & 0.62 & 0.63 & 0.64 & 0.61 & 0.59 \\
\hline Poland & 0.25 & 0.27 & 0.29 & 0.3 & 0.34 \\
\hline Portugal & 0.59 & 0.59 & 0.57 & 0.57 & 0.57 \\
\hline Romania & 0.08 & 0.06 & 0.09 & 0.05 & 0.05 \\
\hline Slovenia & 0.27 & 0.25 & 0.22 & 0.22 & 0.21 \\
\hline Slovakia & 0.27 & 0.3 & 0.51 & 0.22 & 0.22 \\
\hline
\end{tabular}




\begin{tabular}{l|c|c|c|c|c}
\hline Country/Year & 2013 & 2014 & 2015 & 2016 & 2017 \\
\hline Spain & 0.36 & 0.35 & 0.34 & 0.33 & 0.33 \\
\hline Sweden & 0.9 & 0.91 & 0.87 & 0.88 & 0.85 \\
\hline United Kingdom & 0.43 & 0.43 & 0.42 & 0.41 & 0.39 \\
\hline
\end{tabular}

Source: Gross domestic expenditure on $R \& D$ by sector \% of GDP, https://ec.europa.eu/eurostat/ databrowser/view/sdg_09_10/default/table?lang=en [accessed: 21.09.2019].

Analyzing data on the higher education sector shows that this is the second sector in terms of $R \& D$ expenditure in 25 countries. $R \& D$ activity financed by the higher education sector is around $20 \%$ in most countries in the EU.

Table 5 .

Gross domestic expenditure on $R \& D$ by government sector

\begin{tabular}{l|c|c|c|c|c}
\hline Country/Year & 2013 & 2014 & 2015 & 2016 & 2017 \\
\hline Austria & 0.13 & 0.14 & 0.14 & 0.22 & 0.22 \\
\hline Belgium & 0.2 & 0.21 & 0.23 & 0.23 & 0.29 \\
\hline Bulgaria & 0.19 & 0.2 & 0.2 & 0.17 & 0.17 \\
\hline Croatia & 0.21 & 0.2 & 0.21 & 0.18 & 0.19 \\
\hline Cyprus & 0.07 & 0.07 & 0.06 & 0.06 & 0.06 \\
\hline Czechia & 0.35 & 0.36 & 0.39 & 0.31 & 0.31 \\
\hline Denmark & 0.07 & 0.07 & 0.07 & 0.07 & 0.09 \\
\hline Estonia & 0.15 & 0.16 & 0.16 & 0.14 & 0.15 \\
\hline Finland & 0.29 & 0.27 & 0.24 & 0.22 & 0.24 \\
\hline France & 0.29 & 0.29 & 0.29 & 0.29 & 0.28 \\
\hline Germany & 0.42 & 0.42 & 0.41 & 0.4 & 0.41 \\
\hline Greece & 0.23 & 0.23 & 0.27 & 0.25 & 0.25 \\
\hline Hungary & 0.21 & 0.19 & 0.18 & 0.16 & 0.17 \\
\hline Ireland & 0.07 & 0.07 & 0.05 & 0.05 & 0.05 \\
\hline Italy & 0.18 & 0.18 & 0.18 & 0.17 & 0.17 \\
\hline Latvia & 0.18 & 0.17 & 0.16 & 0.14 & 0.13 \\
\hline Lithuania & 0.19 & 0.18 & 0.18 & 0.22 & 0.25 \\
\hline Luxembourg & 0.38 & 0.38 & 0.38 & 0.34 & 0.33 \\
\hline Malta & 0.07 & 0.07 & 0.12 & 0.01 & 0.01 \\
\hline Netherlands & 0.24 & 0.23 & 0.24 & 0.23 & 0.23 \\
\hline Poland & 0.23 & 0.23 & 0.24 & 0.02 & 0.02 \\
\hline Portugal & 0.09 & 0.08 & 0.08 & 0.07 & 0.07 \\
\hline Romania & 0.19 & 0.16 & 0.19 & 0.16 & 0.16 \\
\hline & & & & & \\
\hline
\end{tabular}




\begin{tabular}{l|c|c|c|c|c}
\hline Country/Year & 2013 & 2014 & 2015 & 2016 & 2017 \\
\hline Slovenia & 0.34 & 0.29 & 0.3 & 0.27 & 0.26 \\
\hline Slovakia & 0.17 & 0.25 & 0.33 & 0.17 & 0.18 \\
\hline Spain & 0.24 & 0.23 & 0.23 & 0.22 & 0.21 \\
\hline Sweden & 0.12 & 0.12 & 0.11 & 0.11 & 0.12 \\
\hline United Kingdom & 0.13 & 0.12 & 0.11 & 0.11 & 0.11 \\
\hline
\end{tabular}

Source: Gross domestic expenditure on R\&D by sector \% of GDP, https://ec.europa.eu/eurostat/ databrowser/view/sdg_09_10/default/table?lang=en [accessed: 21.09.2019].

Based on the data presented in table 5 , it can be concluded that only in three countries the R\&D activity financed by the government sector is greater than by the higher education sector. They are Slovenia, Romania and Luxemburg. In the other 25 countries in EU government sector is on the third position in terms of financing R\&D activity.

Table 6.

Gross domestic expenditure on R\&D by non-profit sector

\begin{tabular}{l|c|c|c|c|c}
\hline Country/Year & 2013 & 2014 & 2015 & 2016 & 2017 \\
\hline Austria & 0.01 & 0.01 & 0.01 & 0.02 & 0.02 \\
\hline Belgium & 0.01 & 0.01 & 0.01 & 0.01 & $:$ \\
\hline Bulgaria & 0 & 0.01 & 0.01 & 0 & 0.01 \\
\hline Cyprus & 0.06 & 0.08 & 0.07 & 0.07 & 0.07 \\
\hline Czechia & 0.01 & 0.01 & 0.01 & 0 & 0.01 \\
\hline Denmark & 0.01 & 0.01 & 0.01 & 0.01 & 0.01 \\
\hline Estonia & 0.02 & 0.02 & 0.03 & 0.02 & 0.02 \\
\hline Finland & 0.02 & 0.02 & 0.02 & 0.02 & 0.02 \\
\hline France & 0.03 & 0.03 & 0.03 & 0.04 & 0.04 \\
\hline Greece & 0.01 & 0.01 & 0.01 & 0.01 & 0.01 \\
\hline Italy & 0.04 & 0.04 & 0.04 & 0.03 & 0.02 \\
\hline Portugal & 0.02 & 0.02 & 0.02 & 0.02 & 0.02 \\
\hline Slovenia & 0 & 0 & 0 & 0 & 0.01 \\
\hline Sweden & 0.01 & 0.01 & 0.01 & 0.01 & 0 \\
\hline United Kingdom & 0.03 & 0.03 & 0.03 & 0.04 & 0.04 \\
\hline
\end{tabular}

: - data not available

Source: Gross domestic expenditure on R\&D by sector \% of GDP, https://ec.europa.eu/eurostat/ databrowser/view/sdg_09_10/default/table?lang=en [accessed: 21.09.2019].

Table 6 presented gross expenditure on $R \& D$ by non-profit sector. The share of this sector is in most cases negligible or zero. The reason for such research results 
may be the fact that this group includes the private non-profit institutions sector, including scientific associations and foundations conducting $R \& D$ activities. Thus, their number is generally low in EU countries. However, Cyprus has the biggest gross expenditure on $R \& D$ activity by non-profit sector.

\section{R\&D activity in Poland in terms of intramural expenditure}

It is recognized that the greater the share of applied research and development works, the greater the chance that the results of this work will find their practical application in the production of goods and services. Then, it can contribute to increase innovation and technological advancement both products and services as well as the entire economy ${ }^{15}$.

Internal expenditure on research and development activity due to the type of R\&D activity are divided into expenditure on scientific research, in which basic research, applied research and development work are distinguished ${ }^{16}$.

Table 7 .

Intramural expenditure on R\&D activity by types of R\&D in Poland (mln PLN)

\begin{tabular}{l|c|c|c|c}
\hline Year/Type of R\&D & All & Basic research & Applied research & Development works \\
\hline 2013 & 14423.8 & 5042.7 & 2962.7 & 6418.4 \\
\hline 2014 & 16168.2 & 5420.4 & 3191.7 & 7556.1 \\
\hline 2015 & 18060.7 & 5785.5 & 3669.6 & 8632.6 \\
\hline 2016 & 17943 & 5403.1 & 2824.4 & 9715.6 \\
\hline 2017 & 20578.5 & 5971.5 & 3620.4 & 10986.5 \\
\hline
\end{tabular}

Source: Research and development in Poland in 2017, GUS, US w Szczecinie, Warszawa - Szczecin 2018, p. 27.

Based on the above data, Table 7 shows that development works had the largest share in R\&D in Poland in all five years. Compared to 2013, intramural expenditure on development work increased by $71 \%$, applied research by $22 \%$, and basic research by $18 \%$ in relation to 2017 .

\section{Conclusion}

All the aforementioned results of research indicate that expenditures on $R \& D$ activity are crucially important in order to achieve higher level of innovation. Due to the conducted research in most EU countries a following thesis was formulated: The more funds spent on R\&D activity, the greater the level of innovation was

\footnotetext{
${ }_{15}$ J. Heller, M. Bogdański, Nakłady na badania i rozwój w Polsce na tle wybranych państweuropejskich, „Studia Regionalne i Lokalne” 2005, nr 4(22), p. 67-68.

${ }^{16}$ Podręcznik Frascati, Pomiar działalności naukowo-technicznej i innowacyjnej, Główny Urząd Statystyczny, OECD Publishing, Warszawa 2018, p. 30.
} 
achieved in EIS ranking. Indeed, this is not the only determinant of the increase in the level of innovation in a given country. However, this is a specific basis for further development. Countries should focus on the effectiveness of investments in the $R \& D$ sector. The relation of expenditures on the $R \& D$ activity to the final effects would allow to answer the question how effective are the expenditures. In addition, it is easier to monitor expenditures on R\&D having knowledge about the exact innovation process by Schumpeter's theory. Not every expenditure on $R \& D$ is equal to innovation. In the era of technological progress today, the activity of $R \& D$ is exposed to many unsuccessful attempts to achieve innovation. The growing demand of the market means that the traditional factors of production and the increase of their quantity do not lead to economic development and innovation. According to Schumpeter's theory, the secret lies in new combinations of existing production factors. What is more, intangible resources represent an opportunity to develop the level of innovation in a given country and this is a challenge for scientists and researchers of the new economy. Based on the analysis carried out, additional conclusions can be indicated:

1. Developing R\&D area gives the impulse to start the process by research of innovation solutions. Scientific and financial support from government for enterprises in order to start $R \& D$ activity contributes to the increase of innovation, market observations confirmed.

2. In most EU countries the structure of expenditure on R\&D by institutions/ organizations financing this activity is in the following order due to the largest share: business sector, higher education sector, government sector and non-profit sector.

3. The structure of internal expenditure on R\&D in Poland looks as follows: development work $-53 \%$, basic research $-29 \%$, applied research $-18 \%$.

\section{Literature}

Drucker P.F., Innowacje i przedsiębiorczość. Praktyka i zasady, PWE, Warszawa 1992.

Fonfara K., Marketing partnerski na rynku przedsiębiorstw, PWE, Warszawa 2014.

Heller J., Bogdański M., Nakłady na badania i rozwój w Polsce na tle wybranych państw europejskich, „Studia Regionalne i Lokalne” 2005, nr 4(22), s. 67-68.

Janasz W., Kozioł K., Determinanty działalności innowacyjnej przedsiębiorstw, PWE, Warszawa 2007.

Miarkowski A., Ulżyć innowacjom: Uwagi do projektu zmian w uldze podatkowej na działalność badawczo-rozwojowa, Centrum Analiz Klubu Jagiellońskiego, Kraków 2016.

Podręcznik Frascati, Pomiar działalności naukowo-technicznej i innowacyjnej, Główny Urząd Statystyczny, OECD Publishing, Warszawa 2018.

Pomykalski A., Zarzq̨dzanie innowacjami, Wydawnictwo Naukowe PWN, Warszawa-Łódź 2001.

Research and development in Poland in 2017, GUS, US w Szczecinie, Warszawa, Szczecin 2018. 
Schumpeter J.A., Business Cycles. A Theoretical, Historical and Statistical Analysis of the Capitalist Process, McGraw Hill, New York 1964.

Schumpeter J.A., Teoria rozwoju gospodarczego, Wydawnictwo Naukowe PWN, Warszawa 1960.

Schumpeter J.A., Business Cycles. A Theoretical, Historical and Statistical Analysis of the Capitalist Process, McGraw Hill, New York 1964.

Whitfield P.R., Innowacje w przemyśle, transl. T. Mroczkowski, PWE, Warszawa 1979.

\section{Electronic materials:}

European Innovation Scoreboard 2018, https://www.interregeurope.eu/policylearning/ news/3806/european-innovation-scoreboard-2018/ [accessed: 23.06.2019].

Gross domestic expenditure on $R \& D$ by sector \% of GDP, https: / ec.europa.eu/ eurostat/databrowser/view/sdg_09_10/default/table?lang=en [accessed: 21.09.2019].

Opłacalność inwestowania w badania i rozwój, https://www.pwc.pl/pl/publikacje/assets / ncbr-pwc-oplacalnosc-inwestycji.pdf [accessed: 23.06.2019].

Science and Technology, Research and Development, http://www.oecd.org/sdd/08_Science_ and_technology.pdf [accessed: 23.06.2019].

UK improves innovation performance but drops off EU's leaders group, https://ec.europa. eu/unitedkingdom/news/uk-improves-innovation-performance-drops-eus-leaders-group_en [accessed: 23.06.2019]. 